\title{
Bridging academic research and agribusiness in the recovery of byproducts from swine farming
}

\author{
ESTELA NUNES ${ }^{a^{*}}$, SIMONE PERAZZOLI ${ }^{\mathrm{b}}$, AND JANAINA CAMILE PASQUAL ${ }^{\mathrm{c}}$ \\ ${ }^{a}$ Biotechnological Nucleus, West University of Santa Catarina (UNOESC), Videira/SC, Brazil \\ b Sanitary and Environmental Engineering Academy, West University of Santa Catarina (UNOESC), \\ Videira/SC, Brazil \\ ${ }^{c}$ São Roque Farm, Videira/SC, Brazil and Engineering post graduate programme, Federal University of Santa \\ Catarina (UFSC), Florianópolis/SC, Brazil and Itaipu Technological Park (ITP), Foz do Iguaçu/PR, Brazil \\ ${ }^{*}$ Corresponding author \\ vinhoeagua@yahoo.com.br \\ TEL: +55-49-9994-3762
}

Received: 23 April 2012; Published online: 18 October 2012

Invited paper from the $2^{\text {nd }}$ International ISEKI_Food Conference 2011

\begin{abstract}
Nowadays, food production has the challenging mission to encourage the growth of the rural economy assuring long term sustainability of their natural resources. The qualification of human resources and the generation of new knowledge are the main pillars that give sustainability to agribusiness. Animal protein production is one of the branches of the agribusiness sector. Swine production is recognized as an activity of high pollution potential, producing a large quantity of waste. This study aimed to identify the activities developed in partnership among academic, research and extension institutes in a midsize company of the agribusiness sector, more specifically a swine farm (São Roque Farm) in its sustainable restructuring. An exploratory and quantitative research was developed, which comprehended literature reviews, data collection and analysis of documents from the São Roque Farm. It was considered the period that includes the beginning of the sustainable restructuring of the property (2003) until December 2011. During the analysis of the Sustainable Restructuring Project, special attention was given to the readjustment of the wastewater treatment system and to the energy management and carbon credits, being innovative and pilot projects in the state of Santa Catarina. For this purpose, technologies and knowledge are being developed and applied in treatment of three routes: gaseous, liquid and solid. This pilot project allowed the development of applied studies at undergraduate, masters and $\mathrm{PhD}$ level and the main results achieved are the improvement of understanding and the achievement of technical and financial benefits by connecting agribusiness, academia and government research institutions.
\end{abstract}

Keywords: academic research, environmental management, swine production

\section{Introduction}

Food production has the challenging mission to encourage the growth of the rural economy in order to assure the sustainability of their natural resources in the long term. In this context, Brazil offers advantages with regards to other countries, due to water biodiversity and availability, combined with its expressive agriculture production and favorable climatic conditions to strongly promote the use of renewable sources and reduce emissions of greenhouse gases (Bley, Libânio, Galinkin, \& Oliveira, 2009).

Agribusiness is composed mainly of the activ- 
ities of grain and animal protein production (Bley et al., 2009). The trade balance of Brazilian agribusiness in 1989 was US\$ 13.921 billion and closed at US\$ 94.591 billion in 2011, accounting for almost $37 \%$ of the total exports in the last year (Ministério da Agricultura Pecuária e Abastecimento, 2012). In 2011 Brazil was the 4th largest producer (3.227 thousand tons) behind United States, European Union and China, and exporter ("Associação Brasileira da Indústria Produtora e Exportadora de Carne Suína [ABIPECS]," 2012). Santa Catarina is the largest Brazilian state producer and pioneer in the export of swine meat with an exportation of 183.319 tons in 2011 "Associação Brasileira da Indústria Produtora e Exportadora de Carne Suína [ABIPECS]" (2012), "Empresa de Pesquisa Agropecuária e Extensão Rural de Santa Catarina [EPAGRI]" (2010).

Regarding Mercosul, Brazilian agribusiness is much more organized and in an advanced process of industrialization, but without achieving the status of industrialized food economy (Montoya, 2002). Against this background, this is a challenging segment for research and technological innovation in the search for sustainability. The economic and social progress of many countries and company success depends on the efficiency and effectiveness with which the technical knowledge is produced, transferred, spread and incorporated in products and services (Carvalho, H.G. 2000).

The modernization of production, more than a challenge, constitutes a threat mostly for the small and medium-sized Brazilian companies, whose investment capacity in the update of products and processes is limited (Flores, M.J. 2005). The individualized initiatives of teaching activities, research and business became less sustainable, especially under the economic aspect (Etzkowitz, Webster, Gebhardt, \& Terra, 2000), however, the resources can be utilized more efficiently when members share technical information and develop collaborative efforts (Wade, M. 2001).

The qualification of human resources and the generation of new knowledge are the main pillars which provide sustainability to agribusiness (Bauer, F.C. and Vargas Jr., F.M. 2008). In this sense, the universities have made a historical con- tribution to the economic and industrial development, demonstrating that its relationship with the production sector is a key element to drive innovation and technological development. Besides the mission to train skilled labor and to accomplish research, it exercises an important role in the knowledge extension produced for society. This extension is without doubt the area in which the University has more to contribute to the development of agribusiness (Teixeira, E.C. 1992). Moreover, to translate research in economic development, through the several forms of technology transfer, the traditional teaching role should be reinterpreted in manner as the universities assist the modernization process in the small and mid-sized companies. The Triple Helix model (academic-industry-government relations) attempts to account for a new configuration of institutional forces emerging within innovation systems (Etzkowitz et al., 2000), the technological innovation constitutes currently an essential matter for that model. This bridge is really an imperative for the progress and prosperity of the nation. It is essential to identify the areas of collaboration, co-ordination and mutual support between these sectors for sustainable national progress (Hashim, Khattak, \& Khan, 2009).

According to Chiamovich (1999) the place of innovation is the company, the boundary conditions that allow innovation constitute the site of the university-business dialogue. In this connection, the relationship is synergistic, where the company accesses the scientific knowledge and shares the risks while on deployment, while the university takes advantage of the expansion of understanding of the generation process, transfer and application of technology for teachers/researchers and learning through practical application to their students.

A clear account of the goals and patterns of research that characterize particular fields is a necessary premise to understand why the relationships between university and industry may be important or even necessary (Balcony \& Laboranti, 2006). Thus, the scientific production directed to agribusiness aims to check the possibility to develop the sector, or else, make available by means of research and publications, a new knowledge that allows to seize better the potential of a more effective administration and/or 
the development of new production technologies (Tolói \& Reinert, 2011).

Swine production in intensive farming concentrates a large number of animals in reduced areas and it is often identified as one of the more polluting rural activities and with elevated environmental liabilities. This model of production has its origin in an opportunity that few managers realize: the generation of electricity by biogas from the anaerobic digestion of swine effluent and implementation of Clean Development Mechanism (CDM) projects, aiming to reduce emissions of greenhouse gases and sell the Certified Emission Reductions (CERs) in the carbon market. Through the Swine Waste Treatment System (SWTS), the property has become more than self-sufficient in electricity, has considerably reduced its emissions of greenhouse gases and increased environmental awareness of employees and local community.

This study aimed to identify the activities developed in partnership among academic, research and extension institutes in a mid-sized company of the agribusiness sector, more specifically a swine farm, in its sustainable restructuring.

\section{Materials and Methods}

For the development of this work, it was necessary to conduct exploratory and quantitative research by case study, starting from research of quantitative and exploratory character, using comprehensive bibliographic reviews, document data and analysis of documents from the São Roque Farm. The study period was considered the beginning of the sustainable restructuring of the property (2003) until December 2011.

\subsection{Place of study and brief history of São Roque Farm}

São Roque Farm is located in Videira, West of Santa Catarina. The municipality is situated in Rio do Peixe Valley (region where the swine production has great economic representativeness) and is located $400 \mathrm{~km}$ from the state capital, Florianópolis (Figure 1).

The Farm is a Piglet Producer Unit (PPU) that initially (2003) had 3.400 sows and 20.600 pigs.

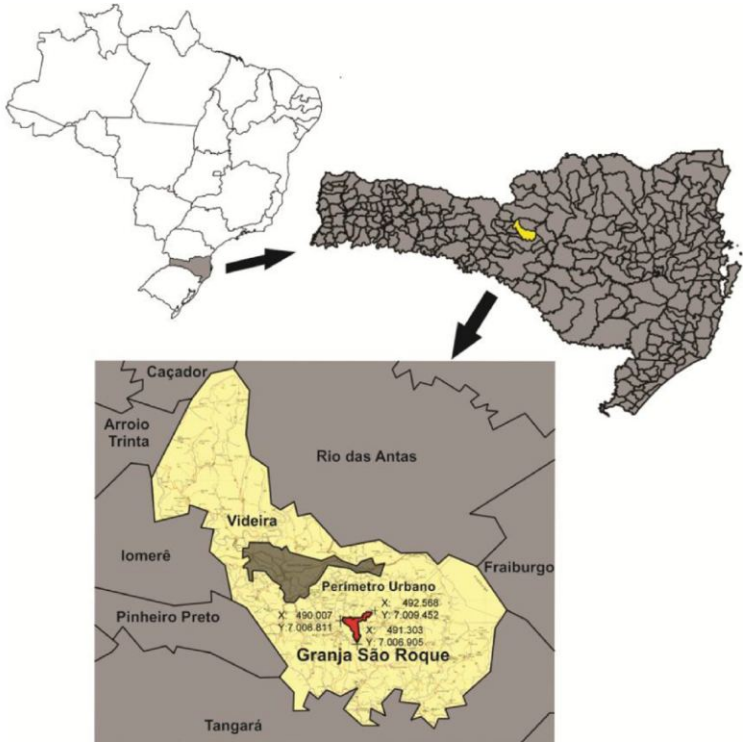

Figure 1: Location of the São Roque Farm (Videira - SC)

Currently (2011) the property is divided into three units (São Roque Farm I, Farm II and Farm III) and has 8.500 sows and a population of 47.000 pigs. The property generates on average $360 \mathrm{~m}^{3}$.day ${ }^{-1}$ of wastewater, consisting of feces, urine, feed residue, hair, cleaning agents, and significant volumes of water which is used in the cleaning and sanitization process. The farm was built in the 1970s, the period in which swine production began to be developed on an industrial scale, without significant advances in the implementation of appropriate environmental systems of wastes, therefore, with high environmental liabilities. In 2003 the property was acquired by a new owner and a new management model started to be developed. A modernization and upgrading environment project was developed.

This property was chosen because it presented a challenging environmental management project; which had the necessity to implement the correct disposal of its effluents and waste, in order to attend the environmental law. Another reason was because some studies were conducted in the property by authors of this paper through universities and laboratories. 


\subsection{Sustainable Restructuring Project}

The sustainable project was developed, under the following steps:

Environmental readjustments these were made in order to accomplish environmental regulations. Under the previous management the property had significant environmental liabilities and several animal facilities have been interdicted by lack of technical and sanitary conditions. Besides, there was a complete lack of management of water use, which generated a great volume of wastewater.

Water management initially it was necessary to conduct a study of all the water used in the property in order to optimize its use.

Treatment Effluent System two independent (with the same project conception) treatment plants were implemented: São Roque I and II (Figures 2 and 3). Initially, each system is composed of flow equalization, settling vessel (solid separator), anaerobic pond (Plant I - 2 units and Plant II -3 units), facultative pond, maturation pond and built wetlands (2 units).

Management of swine waste the transformation of waste in feedstock for electricity generation, carbon and fertilizer, enabling the property to generate new revenues through the conservation of the environment was obtained.

Feed mill to reduce costs and assure the quality and quantity of feed to the farm squads.

\subsection{Bridging Academia and São Roque Farm}

The project that gave support to the model adopted was named "Sustainable Restructuring"

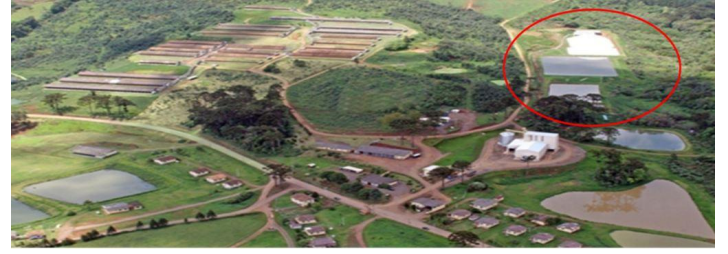

Figure 2: Partial view of São Roque Farm and Wastewater Treatment Plant I

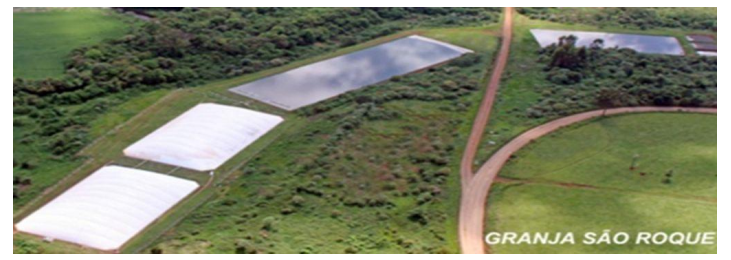

Figure 3: Partial view of Wastewater Treatment Plant II

and has as its basic characteristic the strong bridge with academic and research institutions, promoting partnerships between public and private sectors. For this purpose, a multidisciplinary team was formed, composed primarily of managers, agronomists, engineers, surveyors, veterinarians and lawyers, who together developed the projects mentioned in this research. So, the composition of the team was selected with several experts in each area of expertise, renowned academy institutions and their students, private and public companies linked to research and development equipment.

The partnerships were: West University of Santa Catarina (UNOESC), Federal University of Santa Catarina (UFSC), Brazilian Agricultural Research Corporation (EMBRAPA swine and poultry), National Service of Industry (SENAI/SC), Santa Catarina Central Electric Energy (CELESC), SC - Gas Company and Itaipu Binacional.

\section{Results and Discussion}

In order to check if it is possible to develop swine production in a sustainable manner, this study focuses on the environmental management held in a piglet production unit, located in Videira, West of Santa Catarina. This project was con- 
ducted in partnership with academic and research institutions, promoting partnerships between public and private sectors.

\subsection{Sustainable Restructuring}

During the analysis of these points, is important to remember that the Sustainable Restructuring Project had an initial goal, which was to make the adjustments necessary in the PPU to meet the sanitary and environmental standards, as well as of the integrative company. After this first outcome, special attention was given to energy generation management and carbon credits, mainly for being itself an innovative and pilot project in the state of Santa Catarina. In order to develop it, the property divided and focused its wastes and effluents treatment into three routes:

Solid Route Solid waste resulting in specific case from composters, settling and anaerobic sludge (biodigestor). The proposal to this route is biofertilizer production in a dry and stabilized form. When the present study was concluded, the action plan was started by a partnership between São Roque Farm and Embrapa-Swine and Poultry with the goal of evaluation and validation of a new treatment system for this purpose.

\section{Liquid Route :}

Control and optimization of the treatment plants: Control and optimization of the wastewater treatment system was conducted in partnership with the extension activities of Water and Wastewater Laboratory (UNOESC-Videira) during the period 2006-2010.

The overall removal efficiency of the system was less than $80 \%$ and with the implementation of control and monitoring the overall efficiency (25 indicative parameters) inproved to an average of $99 \%$, reaching $98 \%$ and $100 \%$ for BOD5 and fecal coliforms removal, respectively.

The initial aim was the adequacy of the treatment plants (ponds system) trying to find the conditions of discharge in rivers. The target was achieved, by the necessary development of several meetings (among owners, employees, suppliers and multidisciplinary team) related to the used cleaner technologies. This was done by review of the materials used in the management of pigs, as well as detergents and disinfectants used in cleaning of the facilities.

The system of "built wetlands" was undoubtedly the most sensitive unitary operation of the wastewater treatment plant, which suffered greatly from any fluctuations in effluent quality, mainly to nutrients phosphorus and ammonia nitrogen (data not shown).

At the beginning of 2009, the anaerobic ponds were transformed into biodigesters. Five digesters were installed in the property. After the installation of the biodigesters, necessary alterations in the biomass transfer (quality and quantity) were made. As a result, there was destabilization of the treatment systems and a new work of adjustment to environmental regulations (Resolution from National Environmental Council - Conselho Nacional do Meio Ambiente, CONAMA (2012) n ${ }^{\mathrm{O}}$ 357/2005) was being carried out when this work was concluded.

Efficient water reuse: when this work ended new partnerships were being studied to address the analysis of the liquid route from the property, to establish health and environmental standards for wastewater reuse activity as a subsidy for conservation and efficient use of water.

Gaseous Route Since September 2009 the farm generates about 2,000 $\mathrm{m}^{3}$.day ${ }^{-1}$ biogas (with a mean amount of $66 \% \mathrm{CH}_{4}$ ), with a monthly average of $138,000 \mathrm{~kW} \cdot \mathrm{h}^{-1}$ in electric power. This represents a saving of approximately US $\$ 8.900 /$ month, or $52.2 \%$ of the production. From June 2011 the surplus $(47.8 \%)$ started to be sold, with an income prospect of US\$13.900/month. The energy system is directly connected to CELESC (local distribution line) under the techni- 
cal requirements of National Electric Energy Agency (ANEEL). The gaseous route was defined, however improvements are being sought:

Energy Efficiency Analysis: To be generating electricity from renewable sources, São Roque Farm is conducting a study to optimize the energy resources of the property and contribute to the environment. This project is being developed in partnership with SENAI National and State level and SC-Gas Company.

Carbon credits: The Clean Development Mechanism (CDM) of São Roque Farm is already registered in the United Nations (UN) under AMS III.D - Version 14 "Methane recovery in animal manure management system", established by United Nations Framework Convention on Climate Change (UNFCCC) and it is on progress validation by a Designated Operational Entity. The project is qualified as a small-scale project in agreement with the methodologies of the Intergovernmental Panel on Climate Change (IPCC), which predicts a reduction of emissions of greenhouse gases in 9.154 tons $\mathrm{CO}_{2}$.year ${ }^{-1}$. After all the approvals, the Certified Emission Reduction (CER) will be traded.

\subsection{Bridging academic research}

To establish the bridge between academic research and agribusiness it is especially important to understand the restrictions that often create difficulties or block the success of sharing technical information and development of collaborative efforts.

Flores, M.J. (2005) identified critical points in small and midsize companies as limiting factors of the technological innovation: the nature of the sector in which it is connected, resource restrictions and lack of awareness about the gains brought through innovation process. However, the present study opposes the two latter barriers. The first limiting factor (financial) could be overcome by linking in the Triple Helix model, where it was possible to invest US\$ 1.705 .113 of own resources and funding from partner institutions (public and private sector). The second limiting factor was not observed because the company had the capacity to promote the bridge with academic and research institutions, improving partnerships between involved sectors which was a characteristic observed during the entire project execution. Despite the company studied being located in a rural area, where it often caused some limitations of transportation and communication, these difficulties were overcome by the dynamic and committed management system.

The rigor and commitment of employees were crucial for the successful implementation of knowledge and new technologies. Several experiments made by undergraduate (by extension activities in control and optimization of the wastewater treatment plants) and postgraduate students (specialization, master (Pasqual, J.C. 2011) and PhD degree) in laboratory scale/pilot plant with subsequent success in the application in real plant were and are being conducted in São Roque Farm (Table 1). A practical example is the work done by a $\mathrm{PhD}$ student studying the removal of nitrogen and phosphorus by Lemna minuta in order to use biomass of these plants as nutritional supplement to fish to be cultivated in ponds supplied with treated wastewater (Caris, Nunes, \& Philippi, 2009). This resulted in the development of a new tool that will allow the rural producer, in a visual way, to estimate the nitrogen amount in the water-growing Lemna minuta (Caris, Andrade, \& Philippi, 2010), i.e., through a color palette (Figures 4 and 5).

Also relevant was the generation of employment on this farm for two students (graduate and master level) during and after the project activity, which is positive for both; the company has a trained professional and the university accomplishes its fundamental role to enable and to orientate its egress in his professional life.

\section{Conclusions}

By data collection on the property, it was concluded that environmental management held in the farm provided a significant reduction of their environmental liabilities and transformed the swine wastes into a new source of income through the generation of bioenergy and credits carbon,

\begin{tabular}{l|l|l|l} 
IJFS & October 2012 & Volume 1 & pages 179-187
\end{tabular} 
Table 1: Studies of postgraduate level developed in the São Roque Farm

\begin{tabular}{lcc}
\hline \multicolumn{1}{c}{ Title } & Study Level & Year \\
\hline $\begin{array}{l}\text { Performance of floating macrophytes in the bio-remediation of } \\
\text { swine wastewater }\end{array}$ & PhD & In press \\
$\begin{array}{l}\text { Bioenergy projects and carbon credits: of the liability to the en- } \\
\text { vironmental sustainability on a swine farm }\end{array}$ & Master & 2011 \\
$\begin{array}{l}\text { Biological tretament of the effluent of swine production, an option } \\
\text { in aggregation value and mitigation of environmental damage in } \\
\text { rural properties }\end{array}$ & Specialization & 2009 \\
$\begin{array}{l}\text { filtration system for polishing of effluent from ponds applied to } \\
\text { the swine manure }\end{array}$ & Specialization & 2009 \\
\hline
\end{tabular}
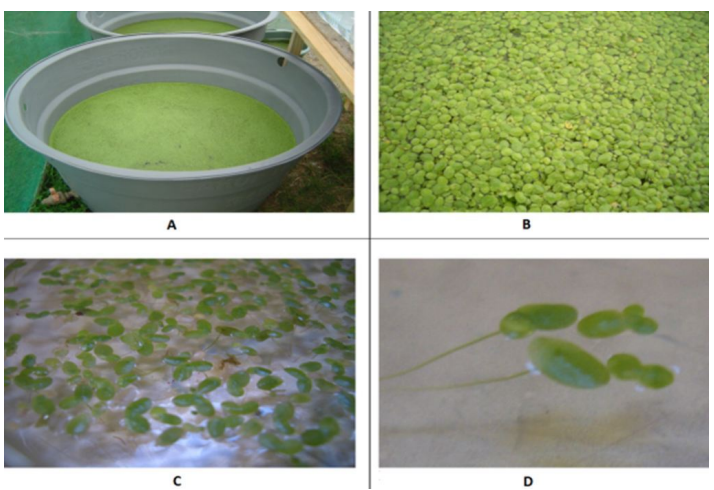

Figure 4: Lemma minuta ilustrative images. A) grow stock tank; B) experimental boxes surface; C) full size view and $\mathbf{D})$ roots observation under stereoscope $(2.5 \mathrm{X})$

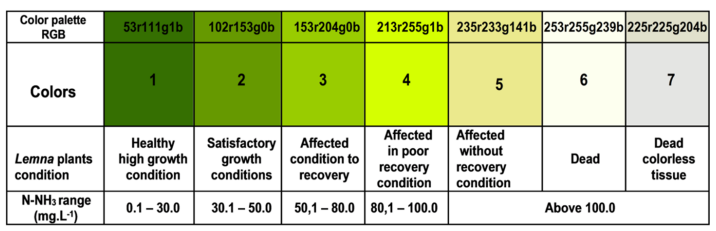

Font: Caris (2010)

Figure 5: Front colorimetric chart that demonstrate Lemma minuta physiologic conditions when exposed to the different amounts of ammonia nitrogen (concentration range). The numbering correspond to the colors and their respective legend collaborating definitively to the sustainability in food production chain.

The Sustainable Restructuring Project from São Roque Farm that was possible through the application of the Triple Helix (agribusinessacademia-government research institution) allowed us to identify:

The conscience of the collaborators, partners and communities and proves that, in spite of big challenges, it is possible to produce foods with environmental and economic sustainability; That promoting the bridge between academic research and agribusiness has encouraged undergraduate and postgraduate students to live the challenges and the complexity of the applied research; That the multidisciplinary approach was fundamental to the development of a successful model of environmental management. Therefore, the integration through partnerships among academia, research institutions and extension is strongly recommended.

\section{Acknowledgements}

Granja São Roque for the data availability, Itaipu Binacional for the intellectual and financial support, UNOESC-Videira for the collaboration and technical support. 


\section{References}

Associação Brasileira da Indústria Produtora e Exportadora de Carne Suína [ABIPECS]. (2012). Produção Mundial de Carne Suína. Retrieved in August 1, 2012, from http: / / www . abipecs . org . br / pt / estatisticas / mundial/exportacao.html.

Balcony, M., \& Laboranti, A. (2006). Universityindustry interactions in applied research: The case of microelectronics. Research Policy, 35(10), 1616-1630. 7th Triple Helex Conference, Turin, ITALY, MAY 18-21, 2005. doi: $\{10.1016 /$ j.respol.2006.09.018\}

Bauer, F.C. and Vargas Jr., F.M. (2008). Produção e gestão agroindustrial. Campo Grande: UNIDERP, 285p.

Bley, C., Libânio, J., Galinkin, M., \& Oliveira, M. (2009). Agroenergia da Biomassa Residual: perspectivas energéticas, socioeconômicas e ambientais. $2^{a}$ Ed. Foz do Iguaçu/Brasília. Technopolitik Editora, 140p.

Caris, M., Nunes, E., \& Philippi, L. (2009). Caracterização de macrófitas e monitoramento de nutrientes em águas residuárias provenientes da suinocultura em duas regiões subtropicais distintas (estado de Santa Catarina, Brasil). Revista Evidência, 7(2), 102-118.

Caris, M., Andrade, A., \& Philippi, L. (2010). Determinação do potencial de biorremediação de nutrientes e bioindicação de águas residuárias da suinocultura por macrófitas flutuantes (Lemna minuta) Efeito de altas taxas de nitrogênio amoniacal. Revista Evidência, 8(1-2), 85-102.

Carvalho, H.G. (2000). Inteligência competitiva tecnológica para PME's através da cooperação escola-empresa: proposta de um modelo. Tese de Doutorado, Universidade Federal de Santa Catarina, Florianópolis, Brasil. 322 p.

Chiamovich, H. (1999). Por uma relação mútuamente proveitosa entre universidades de pesquisa e empresas. Revista de Administração, 34 (4): 18-22. Retrieved in April 19, 2012, from http://www.rausp. usp.br.

Conselho Nacional do Meio Ambiente, CONAMA. (2012). Resolução n $\mathrm{n}^{\underline{0}} 357$ de março de 2005 - Dispõe sobre a classificação dos corpos de água e diretrizes ambientais para o seu enquadramento, bem como estabelece as condições e padrões de lançamento de efluentes, e dá outras providências. Ministério do Meio Ambiente. Brasil, 22 p.

Empresa de Pesquisa Agropecuária e Extensão Rural de Santa Catarina [EPAGRI]. (2010). Síntese Anual da Agricultura de Santa Catarina, 2009-2010. Retrieved in August 4, 2012, from http://cepa.epagri. sc.gov.br.

Etzkowitz, H, Webster, A, Gebhardt, C, \& Terra, B. (2000). The future of the university and the university of the future: evolution of ivory tower to entrepreneurial paradigm. Research Policy, 29(2), 313-330. doi:\{10. 1016/S0048-7333(99)00069-4\}

Flores, M.J. (2005). Contribuições da cooperação universidade-empresa para a capacitação tecnológica de PME's Moveleiras: O Pólo de Arapongas. Dissertação de Mestrado. Universidade Federal do Paraná, Curitiba, Brasil. 150 p.

Hashim, S., Khattak, B., \& Khan, A. (2009). Promoting Industry Academia Linkage for Developing the Knowledge Based Enterprise Sector: A Case Study of D. I. Khan. Journal of Managerial Sciences, 3 (2), 228-235. Retrieved in April 19, 2012, from http:// www.qurtuba.edu.pk/r.

Ministério da Agricultura Pecuária e Abastecimento. (2012). Estatísticas e dados básicos de economia agrícola. Brasília: CGOE. 42 p.

Montoya, M. A. (2002). O Agronegócio no MERCOSUL: dimensão econômica, desenvolvimento industrial e interdepend ência estrutural na Argentina, Brasil, Chile e Uruguai. Revista Brasileira de Economia, 56(4), 605-660. doi:\{10 . 1590 / S0034 $71402002000400004\}$

Pasqual, J.C. (2011). Projetos de bioenergia e créditos de carbono: do passivo à sustentabilidade ambiental em uma propriedade suinícola. Dissertação de Mestrado. Universidade Federal de Santa Catarina, Florianópolis, Brasil. 124 p. 
Teixeira, E.C. (1992). Política agrícola e desenvolvimento. Viçosa: Universidade Federal de Viçosa. 210 p.

Tolói, R., \& Reinert, J. (2011). Contribuição do programa de pós-graduação em agronegócio da Universidade Federal de Mato Grosso do Sul no desenvolvimento do agronegócio do Estado de Mato Grosso do Sul, Brasil. Acta Scientiarum. Human and Social Sciences, 33(1), 55-65. doi: $\{710$. 4025/actascihumansoc.v33i1.7647\}

Wade, M. (2001). Improving agribussines education, research and industry interaction through educational coalitions. In: Series 2001 Annual Meeting. Paper presented at American Agricultural Economics Association. Held at Chicago, Illinois, August 5-8, pp. 1-11. 